\title{
THE LOWER PERMIAN INSECTS OF KANSAS PART 3. THE PROTOHYMENOPTERA
}

\author{
By F. M. CARPENTER*
}

Museum of Comparative Zoology, Cambridge, Mass.

The order Protohymenoptera was established by Tillyard (1924) to include a series of fossil wings contained in the Yale collection from the Lower Permian of Kansas. As indicated by the name, Tillyard believed that this group was ancestral to the Hymenoptera and was sufficient to prove that the Hymenoptera originated independently from the rest of the holometabolous insects (1926b). While it is true that certain morphological features of the Hymenoptera, such as the reduced wing venation, and the polynephric Malpighian system, remove the group from the true panorpoid orders; the results of morphological studies (Crampton, 1919, 1927) indicate that the Hymenoptera arose from the same stem as all the other insects with a similar metamorphosis. ${ }^{1}$ It is therefore advisable for us to submit any paleontological evidence which seems inconsistent with this view to the carefullest examination.

Aside from phylogenetic consideratons, the question of the affinities of the Protohymenoptera has close bearing on the interpretation of the wing venation in the Hymenoptera; for the specialized condition of the wings in the Hymenoptera has prevented entomologists from satisfactorily homologizing the veins with those of other insects. As a result, a number of different systems of venational

* National Research Fellow, Harvard University. These studies have also been aided by grant No. 280 of the Bache Fund, National Academy of Sciences, and a Sheldon Traveling Fellowship from Harvard University. Part 1 (Introduction and the Order Mecoptera) was published in the Bulletin of the Museum of Comparative Zoology 70 (2), 1930; Part 2 (Paleodictyoptera, Protodonata, and Odonata) will appear in the American Journal of Science, 21 (2), 1931.

${ }^{1}$ Handlirsch, however, has held the opposite view (1906-08). 
nomenclature are being used in the Hymenoptera, each more or less limited to a certain group of families. Comstock, MacGillivary, and a few others have proposed systems intended to homologize the venation with that of other groups, but hymenopterists in general have not accepted these schemes. More recently Tillyard has advanced a new and radically different system (1924) based on the assumption that the Protohymenoptera exhibit the primitive condition of the venation in the hymenopterous line of descent; and he believes that through this interpretation the whole of the homologies of the veins at once "becomes clear and of the utmost simplicity" (1926c, p. 256).

Let us consider briefly the opinions expressed by other entomologists on the affinities of the Protohymenoptera, and on the new system of venation in the Hymenoptera, based on these fossils. Lameere (1927) accepts the insects as representatives of the group ancestral to the Hymenoptera, and also adopts the venational interpretation, with a few slight modifications. Handlirsch (1927), however, has briefly (without discussion) suggested that the fossils are more closely related to the Megasecoptera than to the Hymenoptera, and may actually belong to that order. Cockerell (1927) appears to accept the fossils as of hymenopterous nature, but suggests some changes in the interpretation of the veins. Crampton (1927) agrees that the fossils are hymenopterous and he favors the venational system.

Martynov has studied the question more thoroughly. In 1928, while collecting insects in the Permian beds (Kazan) of Northwest Russia, he discovered a single wing which resembles both the Kansan Protohymenoptera and certain Carboniferous Megasecoptera. From his study of this fossil and the Kansan specimens in the Yale collection, he concluded that the Protohymenoptera were really close to the Megasecoptera, and not related to the Hymenoptera. "They belong to my subdivision Paleoptera containing all orders, chiefly extinct, in which the wings were outspread when at rest. Indeed, both Protohymen permianus Till. and Permohymen schucherti Till. were found in the outspread condition of the wings, and even Tillyard thinks 
that such a discovery 'suggests very strongly that the insects of this family rested with outspread wings, as did the Palæodictyoptera and Megasecoptera.' It is true that among Asthenohymenidæ specimens 'occur, in which one wing is laid exactly over the other,' but the same takes place in the case of the Zygoptera, and this manner of resting in Zygoptera in no way proves that they are allied to the Hymenoptera or to any other Holometabola or even Neoptera. When an insect of the division Neoptera, for instance a Neuropteron, puts its wings on the dorsum in roof-shaped manner, the upper surface of the wings is exposed upwards and outwards, with costal borders placed beneath, along the support. On the contrary, in Zygoptera, as also in some Agnatha, when at rest the upper surfaces of the wings are turned inwards, with the dorsal borders looking upwards, i. e., the manner of folding the wings at rest is very different in the Zygoptera and in the Neoptera. Perhaps some forms of Protohymenoptera could 'fold' their wings back on the dorsum, but such 'folding,' in all probability, recalled that of the Zygoptera or of the Agnatha, but not of the Hymenoptera or Copeognatha, or in general, of the Neoptera. Further, such facts as that the fore and hind wings in the 'Protohymenoptera' were of almost equal size, had the same wing venation, were not linked together in flight by hooklets, or by any hairs, and had some veins, at least the costa and the radius 'serrated along its outer edge, in exactly the same manner as that in Odonata,' clearly manifests that the whole order belongs to the division Paleoptera and is allied partly to the Megasecoptera, partly to the Odonata and Protodonata. The membrane of the wings was glassy, as in Agnatha or in Megasecoptera or in Odonata. Many Neuroptera, Mecoptera and Hymenoptera and even some Trichoptera have also a glassy membrane, but in these groups the wing membrane is furnished not only with chetoids . . . but also with numerous true hairs. In the wings of the Hymenoptera both chetoids and hairs are present everywhere, though the hairs sometimes become very small, minute. The wing membrane in the Odonata and Agnatha, as well as, probably, in Megasecoptera, is really glassy, i. e., perfectly deprived of both hairs and chetoids. One should suppose 
that in the group ancestral to the Hymenoptera we must inevitably find some remains of hairs, similar to those which exist, for example, in the wings of the fossil Mecoptera. Thanks to the kindness of Professor Schuchert ... I examined the excellent remains of both Protohymen and Permohymen, but I could not perceive any hairs on their wings. The wing of the new genus Aspidohymen from Tikhie Gory also does not show any traces of hairs. Thus, such a character of the wing membrane manifests also that this order is very far removed from the order Hymenoptera, as well as from the remaining Holometabola, and is allied rather to the order Odonata, etc., i. e., belongs to the division Paleoptera." (1930, p. 79.)

In 1927, one year previous to Martynov's discovery of the Russian specimens, I was fortunate enough to secure fifty-five representatives of the Protohymenoptera in the limestone at Elmo, Kansas. At that time it was already clear that a knowledge of the structure of the body of these insects would help us immensely in determining their affinities. Since the Yale specimens consisted only of wings, the chief aim of our collecting trip was to obtain specimens of Protohymenoptera with the body preserved. In this respect we were most successful ; several fossils show portions of the bodies, and one specimen includes nearly the whole body, with the minutest details perfectly preserved. Through the kindness of Professor Dunbar I have been able to examine the twenty-three specimens of Protohymenoptera in the Yale collection, including Tillyard's types; and I have also found four additional fossils in Dr. Sellards' collection. From my study of all these representatives of the group, totaling eighty-two, I am convinced that Handlirsch and Martynov were correct in their assumption that the Protohymenoptera were megasecopterous. The evidence which leads me to this conclusion will be presented after the description of the fossils.

It will be observed in these descriptions that I have employed an interpretation of the venation which differs from that used by Tillyard, as well as from that offered by Martynov. These changes in the nomenclature of the veins are necessary because both of these authors have been mislead by an erroneous conception of the convexities 
and concavities of the veins. The evidence for this will also be considered after the descriptions.

The Kansan Protohymenoptera were separated by Tillyard into two families, Protohymenidæ and Asthenohymenidæ, based largely on the degree of development of the pterostigma, the presence or absence of the radial sector, and the relative lengths of the second anal vein. This classification is a convenient one and is used here, but the most striking difference between the families lies in the width of the costal space. The second of the characteristics mentioned by Tillyard must be omitted, for the radial sector is present in all forms. One change in the terminology of the families must be made. In 1906 Sellards described one of the Kansan fossils in his collection as Doter minor; this specimen consisted of the thorax, abdomen, two long cerci, and the two front wings, but the latter were so twisted and folded that he was unable to determine satisfactorily the nature of the venation. He was not sure of the taxonomic position of the fossil, but believed that it was related to the Protephemeroidea. Handlirsch (1919) placed it within a separate family, Doteridæ, and doubtfully considered it to be a Paleodictyopteran. When I examined this type specimen in 1927 at Austin, Texas, I observed at once from the nature of the wing membrane and the venation that it belonged to the genus Asthenohymen, which Tillyard had just described. From the photograph, drawings, and notes which I made at that time, I am now able to recognize it as the same species which Tillyard called $A$. dunbari, the commonest of all the Protohymenoptera in the Elmo limestone. Of course this identity is not obvious from Sellards' figure of Doter minor, for the distortion of his fossil and the fact that the insect possessed an unusual type of venation prevented Sellards from obtaining a correct idea of the venation. This synonymy requires us to change the name of the genus from Asthenohymen to Doter, and the corresponding family name to Doteridæ. It is interesting to note that Dr. Martynov has observed $(1930$, p. 85$)$ a similarity between the venation of Doter, as figured by Sellards, and the venation of Asthenohymen, and he has suggested that Doter may be a Protohymenopteron. Dr. Martynov deserves to be con- 


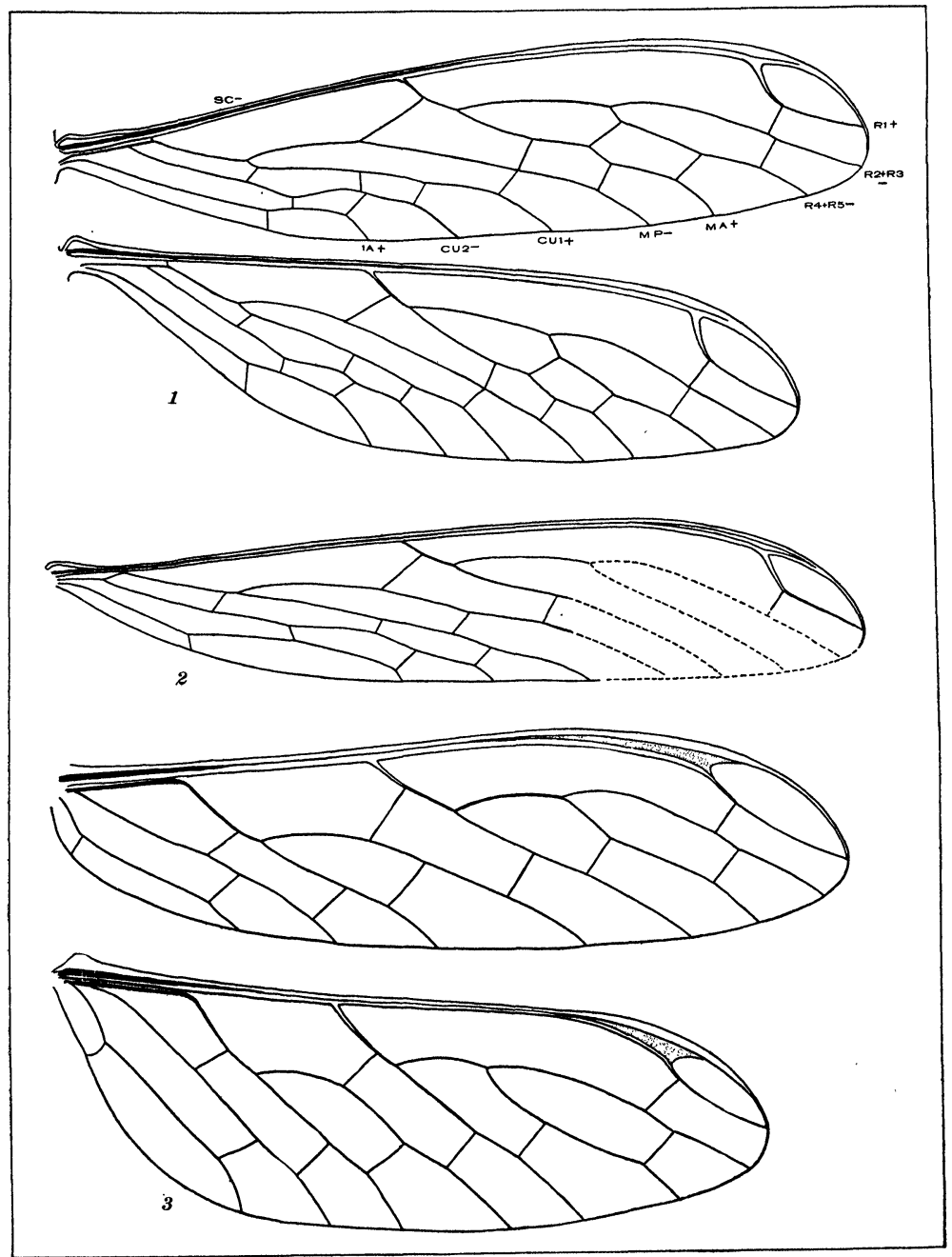

Carpenter-Permian Insects. 
gratulated on the keenness of his observation and the accuracy of his conclusion.

\section{FAMILy PRotohymenidae}

Fore wing: costal margin very slightly convex, nearly straight; costal space present at very base of wing only; Sc rather long, extending a short distance beyond the origin of $\mathrm{Rs} ; \mathrm{R}$ close to the costal margin, except at the very base; R1 diverging downward distally, away from the pterostigma; pterostigma very slender; $\mathrm{Cu}$ straight at base of wing; Cu1 and Cu2 diverging near the base; 9-14 cross-veins.

Hind wing: a little shorter and broader than fore wing, and differently shaped; venation similar.

\section{Protohymen Tillyard}

Protohymen Tillyard, Amer. Journ. Sci. (5) 8 (44) : 113, 1924.

Fore wing; very slender, subpetiolate; $\mathbf{R}$ remaining in contact with the costa to the pterostigma and joined to the costal margin by a heavy cross-vein distad of the pterostigma; Cu1 diverging backward directly after its origin; 13-14 cross-veins. The positions of the cross-veins, designated by Tillyard as generic features, are subject to great individual variation; but the cross-vein between $1 \mathrm{~A}$ and the hind margin is always remote from the base of the wing.

Hind wing: more petiolate than fore wing; $\mathrm{Cu}$ more remote from $R^{+} M$ at the base than in the fore wing.

Genotype: Protohymen permianus Tillyard.

Protohymen permianus Tillyard

Figs. 1, 11

Protohymen permianus Tillyard, Amer. Journ. Sci. (5) 8 (44) : 114, 1924. 
Psyche, 1930

Vol. 37, Plate 16.

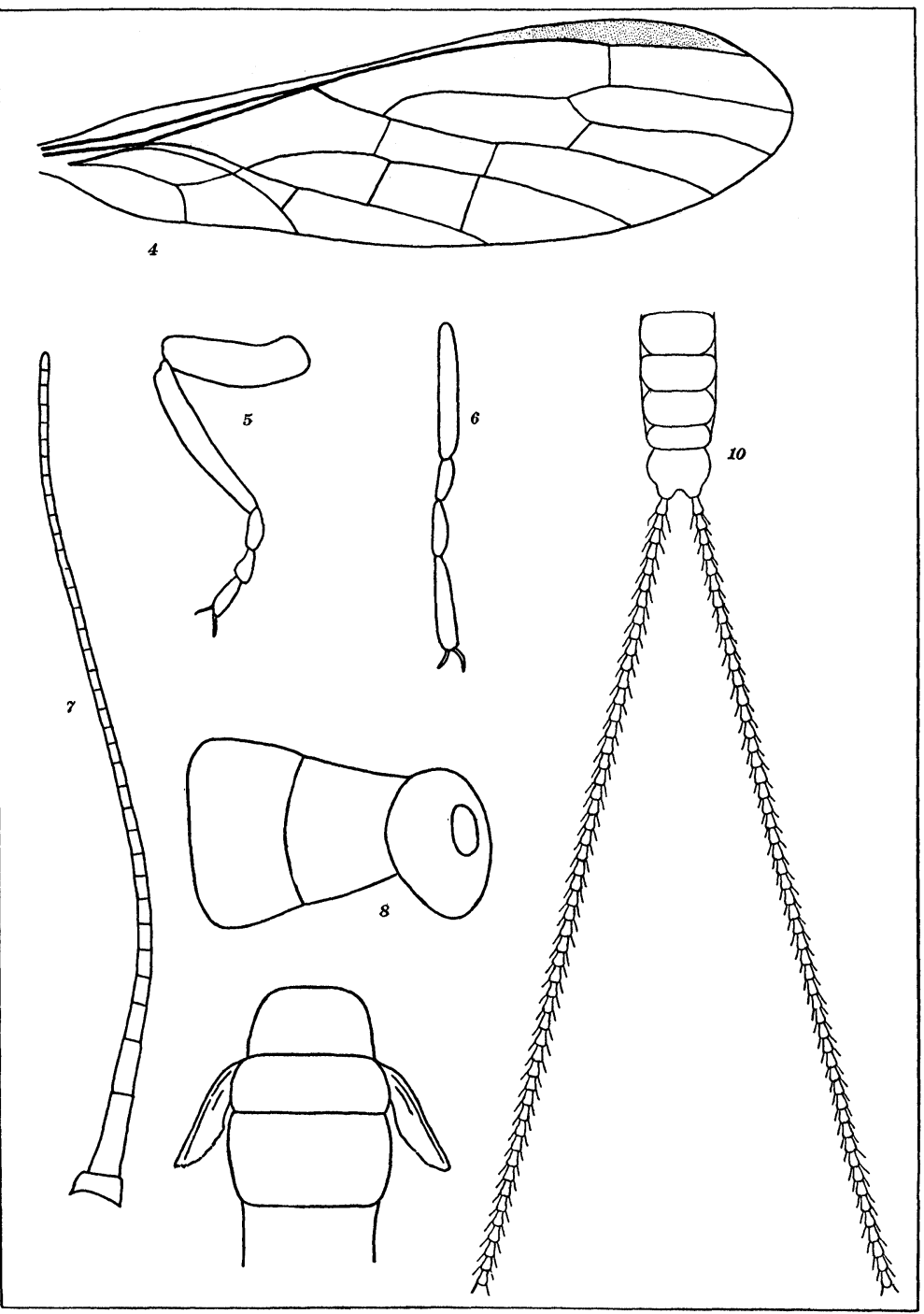

Carpenter-Permian Insects. 
Protohymen permianus Tillyard, Amer. Journ. Sci. (5) 11 (61): 58, 1926.

Fore wing: length, $10-13 \mathrm{~mm}$; width, $3 \mathrm{~mm}$; at the base the costa bends outward slightly, but there is no precostal area; $\mathrm{R}$ comes in contact with the costa before the divergence of $\mathrm{Cu} 1$ and $\mathrm{Cu} 2$, and at the middle of the pterostigma it diverges downward toward the apex; $\mathrm{Cu} 2$ strongly undulated. Cross-veins: one between R1 and $\mathrm{R} 2+3$; one between $\mathrm{R} 2+3$ and $R 4^{+} 5$; two between $\mathrm{R} 4^{+} 5$ and MA; two or three between MA and MP; one between $\mathrm{MP}$ and $\mathrm{Cu} 1$; two or three between $\mathrm{Cu} 1$ and $\mathrm{Cu} 2$; two between $\mathrm{Cu} 2$ and $1 \mathrm{~A}$; one or two between $1 \mathrm{~A}$ and the hind margin; the cross-veins between $1 \mathrm{~A}$ and the hind margin are always attached to the distal half of the anal vein.

Hind wing: length, 9-11 mm.; width, $3.5 \mathrm{~mm}$.; venation nearly identical with that of the fore wing; the length of the oblique vein between MP and $\mathrm{Rs}^{+} \mathrm{MA}$ is less than in the fore wing.

Holotype: No. 5001 (hind wing), Peabody Museum, Yale University; paratype: No. 5002 (fore wing), Peabody Museum; No. 1702, Tillyard collection.

In the Harvard collection there are ten specimens of this species, as follows: No. 3060ab, fore and hind wings complete, with fragments of head and thorax; No. 3061ab, fore and hind wings, folded together, but well preserved; No. 3062ab, hind wing, complete; No. 3063ab, fore wing, nearly complete; No. 3064ab, one pair of fore and hind wings (J. W. Wilson, collector) ; No. 3065ab, hind wing, complete except for the base; No. 3066ab, basal third of wing; No. 3067, middle third of wing; No. 3068ab, distal third of wing; No. 3070ab, basal two-thirds of wing. All specimens collected by F. M. Carpenter, unless otherwise indicated. In the Sellards collection there are two specimens : No. 1068, distal two-thirds of fore wing; No. 1558, distal third of wing.

The holotype specimen of this species is well preserved, but the base of the wing is missing. Since none of the other Yale specimens have this part preserved, Tillyard's figure is incomplete at the base. The wing is longer and more nearly petiolate than he supposed. The subcosta is 
Psyche, 1930.

Plate 17.
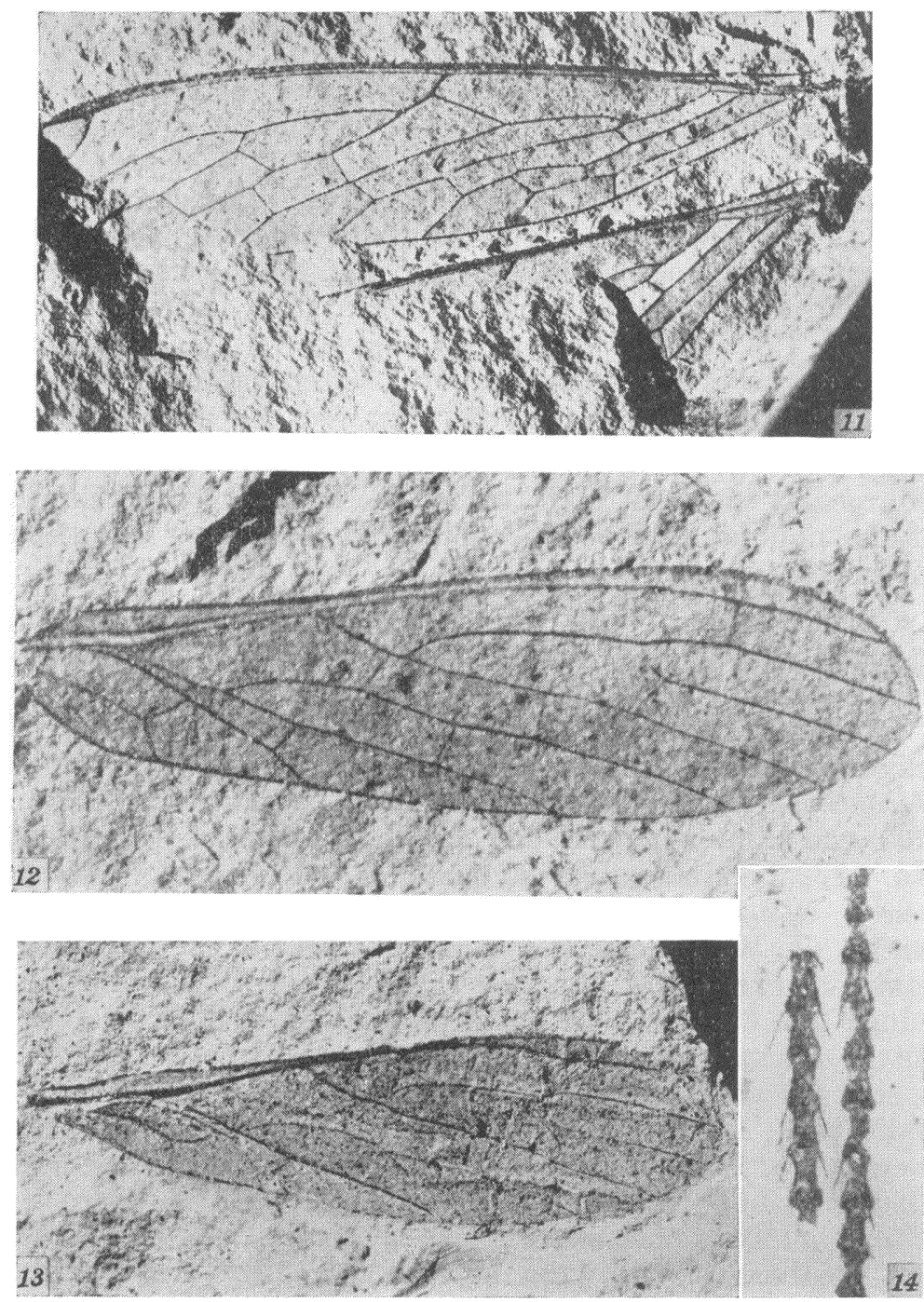

Carpenter-Permian Insects. 
not well preserved in the Yale material, but in several of the new fossils it is very clear; it does not extend to the pterostigma as thought by Tillyard. The pterostigma is also differently formed than shown in his figure; the photograph accompanying his paper (plate 4, fig. 1) demonstrates clearly the true nature of this structure. The costa and R1 widen slightly in the region of the pterostigma, so that there is no space formed between these veins until $\mathrm{R} 1$ diverges towards the apex. $\mathrm{R} 1$ appears to fork here, but in reality, as I shall show later, the upper "branch" which connects R1 to the margin is a modified cross-vein. There is considerable variation in the distribution of the cross-veins, and sometimes a cross-vein may be absent altogether or an extra one added. The holotype specimen has two cross-veins between $1 \mathrm{~A}$ and the hind margin, but all the other specimens I have seen possess only one here. The short vein, resembling a cross-vein, between the base of $\mathrm{Cu} 1$ and $\mathrm{R}^{+} \mathrm{M}$ is apparently the basal part of MP.

\section{Protohymen elongatus $\mathrm{n}$. sp.}

Fig. 2

Fore wing: length, $20 \mathrm{~mm}$.; width, $3.5 \mathrm{~mm}$.; extremely slender and pointed; R1 separating from the costa at the beginning of the pterostigma, so that there is a distinct space between these veins in the region of the pterostigma (text fig. 1); Cu1 diverges upward after its separation from $\mathrm{Cu} 2$, and touches $\mathrm{R}^{+} \mathrm{M}$; $\mathrm{Cu} 2$ only very slightly undulated; cross-veins distributed essentially as in permianus, but the one between $1 \mathrm{~A}$ and the hind margin is attached to the middle part of the anal vein.

Holotype: No. 3069ab, Museum of Comparative Zoology ; F. M. Carpenter, collector.

This species is based on a well-preserved and nearly complete fore wing. The only part missing includes the area between the terminations of MP and R1, along the posterior border. Elongatus can readily be distinguished from the previous species by its more slender habitus and the corresponding tenuity of the veins. 


\section{Permohymen Tillyard}

Permohymen Tillyard, Amer. Journ. Sci. (5) 8 (115), 1924.

Fore wing: very broad; $R 1$ remaining in contact with costal vein only a little beyond the origin of Rs; pterostigmal space wider than in Protohymen, narrowly triangular; R1 without a definite cross-vein between it and the costal margin in the region of the pterostigma; $\mathrm{Cu} 1$ remains parallel to $R^{+} M$ and in contact with it for some distance after its origin; 9-10 cross-veins; cross-vein between $1 \mathrm{~A}$ and the hind margin is attached close to the base of the wing.

Hind wing: much broader than the fore wing, especially at the base; venation similar.

Genotype: Permohymen schucherti Tillyard.

\section{Permohymen schucherti Tillyard}

Permohymen schucherti Tillyard, Amer. Journ. Sci. (5) 8 (44) : 116, 1924.

Permohymen schucherti Tillyard, Amer. Journ. Sci. (5) 11 (61) : 61, 1926.

Fore wing: length, $13 \mathrm{~mm}$; width, $3.5 \mathrm{~mm}$; costal margin bends outward at base; R1 comes in contact with costa just before termination of Sc; Cu2 straight; crossveins: one between $R 1$ and $\mathrm{R2}^{+} 3$; one between $\mathrm{R}^{+} 3$ and $\mathrm{R}^{+} 5$; one between $\mathrm{R}^{+} 5$ and MA; two between MA and MP; one between MP and Cu1; two between $\mathrm{Cu} 1$ and $\mathrm{Cu} 2$; one between $\mathrm{Cu} 2$ and $1 \mathrm{~A}$; one between $1 \mathrm{~A}$ and margin of wing.

Hind wing: length, $12 \mathrm{~mm}$.; width, $4 \mathrm{~mm}$.; pterostigma a little broader apically than in fore wing; venation similar.

Holotype: No. 5003, Peabody Museum; counterpart, No. 1704b, Tillyard collection.

In the Harvard collection there are four specimens of this species, as follows: No. 3071, fore wing complete; No. 
3072a, apical half of wing (fore?) ; No. 3073, hind wing, complete and splendidly preserved; 3074ab, base of hind wing. In the Sellards collection I find one specimen, No. 308 (reverse, No. 309), fore wing, complete except for apex.

The holotype specimen consists of a very nearly complete fore wing and hind wing, with parts of the corresponding pairs. The bases of the fore wings are obscured by an abrupt bend in the surface of the rock, and the bases of the hind wings are missing entirely. Tillyard was therefore not able to obtain a clear vision of the venation at the base of the wings, and his figure of this part is incorrect. $\mathrm{Cu} 1$ is undoubtedly united with $\mathrm{Cu} 2$ at the base of the wing, but it runs along in contact with $R^{+} M$ for quite a distance before diverging backwards; this is essentially the same structure as in Protohymen, only in that genus Cu1 diverges from $R^{+} M$ much nearer to the base of the wing. The subcosta cannot, of course, be seen in the holotype, but it is clearly preserved in several of the Harvard specimens. It is a strongly developed vein, extending only a short distance beyond the posterior divergence of Cu1. The apex of the fore wing is not pointed as figured by Tillyard. The apex of the left wing, on which Tillyard apparently based his figure, is distorted by an irregularity in the surface of the rock. The true shape of the wing is clearly shown in the right wing of the holotype, as can be seen in the photograph accompanying Tillyard's paper (plate 4, fig. 2).

\section{FAMILY DOTERIDAE}

Fore wing: anterior margin slightly concave, the maximum curvature near the base of the wing; costal margin serrated; costal space broad basally, present along the entire anterior margin of the wing; Sc short, not extending as far distad as the origin of $\mathrm{Rs}$; $\mathrm{R}$ remote from the costal margin at the base, approaching nearer to it at the middle of the wing; R1 starts to diverge from the costa near the middle of the wing; pterostigma weakly developed, slenderly oval; frequently the pterostigma is bordered distally by a well-developed cross-vein between $\mathrm{R} 1$ and the anterior 
margin; stem of $\mathrm{Cu}$ curved posteriorly at the base; $\mathrm{Cu} 1$ and $\mathrm{Cu} 2$ diverging close to the base; 7-8 cross-veins.

The fore and hind wings have not been distinguished.

\section{Doter Sellards}

Doter Sellards, Amer. Journ. Sci. (4) 23: 355, 1907.

Doter Handlirsch, Denkschr. Akad. Wiss. Wien. Math. Naturw. (96) 82: 22, 1919.

Asthenohymen Tillyard, Amer. Journ. Sci. (5) 8 (44) : 117, 1924.

Asthenohymen Tillyard, Amer. Journ. Sci. (5) 11 (61) : 63, 1926.

Head small, oval; eyes small, oval, placed close together; antennæ long and slender with about 35 segments, the two basal ones several times as long as broad, the others about twice as long as broad; thorax broad; prothorax long, narrow, mesothorax short, metathorax about twice as long as the mesothorax; legs short and stout; femur and tibia nearly equal in length; 3 tarsal joints, the last bearing a pair of small claws; the last tarsal segment of front legs only a little longer than the others, the last tarsal joint of the middle legs about twice as long as the others; hind legs and basal segments of abdomen unknown; terminal four abdominal segments about twice as broad as long; last segment rounded posteriorly, bearing two very long, slender cerci, consisting of at least 52 segments (probably more), each segment with a pair of divergent hairs.

Wings moderately slender, nearly subpetiolate, apex well rounded; $\mathrm{Rs}$ divides into $\mathrm{R} 2^{+} 3$ and $\mathrm{R} 3{ }^{+} 4$ about half way between its origin and termination; $\mathrm{R} 2+3$ terminates at the very apex; cross-veins constant in number, but variable in position.

Genotype: Doter minor Sellards.

Tillyard placed seven species of the Kansan Protohymenoptera in the genus Asthenohymen. Apparently the members of this genus rested with their wings back over the 
abdomen, as thought by Tillyard, for all the specimens with the four wings preserved are in that position. This condition, of course, obscures or confuses the venation to such an extent that we cannot distinguish satisfactorily the fore and hind wings. Two specimens in the Yale collection are preserved in the position of rest, but both of these lack the bases of the wings. When we consider the species of Doter, therefore, we must bear in mind that we may be describing the fore and hind wings as separate species, although from the condition in the Protohymenidæ we should not expect much difference in the venation.

From a study of the forty-three specimens of Doter in the Harvard collection and the eleven Yale types, I am convinced that several of the species described by Tillyard are not valid. The data on which I base this conclusion follow:

(1) Dunbari. The true shape of the wing of the holotype is not shown in Tillyard's figure. The basal part of the holotype wing was hidden when he studied it by a small piece of the limestone matrix. When I removed this chip of rock, the whole wing was exposed, revealing an outline much like that in Tillyard's figure of affinis. The subcosta is quite clear in the type and is represented in Tillyard's figure, although it is not labeled. The costal space is broader basally than shown in the figure. There is a distinct cross-vein between $R 1$ and $R 2+3$ ( $R$ and $M$, Tillyard), although the supposed absence of this cross-vein was given by Tillyard as a key character.

(2) Affinis. The base of the wing of the holotype is not very well preserved, but nevertheless it shows a broad costal space. I am not sure whether the basal cross-vein between $\mathrm{Cu} 1$ and $\mathrm{Cu} 2$ is present or not; at any rate, the wing is so faintly preserved here that its possible absence in the fossil might easily be due to lack of preservation.

(3) Gracilis. The holotype wing is not so slender as shown in the figure; the costal space is broadened basally even more than represented. The pterostigmal area is distinctly darkened, even more than it is in the type of stigmatazans. A careful examination of the holotype under 
good illumination shows that there is unquestionably a cross-vein between $\mathrm{Cu} 2$ and $1 \mathrm{~A}$ basally, and another one between $1 \mathrm{~A}$ and $\mathrm{Cu} 2$. The supposed absence of these crossveins was used by Tillyard as key characters. 1A does not join $\mathrm{Cu}$ at the base of the wing, but curves downward and away from the stem.

(4) Stigmatazans. The type specimen has a broad costal area at the base, and is shaped like the preceding fossils. The pointed appearance of the apex, as shown in Tillyard's figure, was due to the fact that the anterior margin was covered by a piece of limestone when he studied it. By removing this fragment, I found that the apex was more rounded. The pterostigma, which is slightly darkened, is not so noticeable as that in gracilis. There is no cross-vein visible at the base between $\mathrm{Cu} 1$ and $\mathrm{Cu} 2$, but this absence is due in all probability to the poor preservation at that part of the wing; the cross-vein at the distal ends of these veins is exceedingly faint.

(5) Kansasensis. This wing is not so narrow as shown in Tillyard's figure (see my photograph of the type, fig. 12) ; when I first examined the fossil, the anterior margin was partly covered by a piece of the matrix, but this was removed and the costal area was found to be as broad as in the other fossils. The removal of this chip also exposed the subcosta, which is partly shown in Tillyard's figure, although it seems to have been confused by him with the base of the radius. The type specimen is splendidly preserved and is one of the best representatives of Doter which I have seen.

(6) Stenobasis. The apical portion of the holotype wing was not missing, as stated by Tillyard, but only covered by the limestone. When this matrix was removed and the whole wing exposed, I found that the shape was identical with that of affinis; the costal area is broadened basally. The pterostigmal area, not seen by Tillyard, is fully as dark as that in stigmatazans. Even under the best illumination and highest power of binocular magnification I could not discern $1 \mathrm{~A}$ in the type, or the two crossveins shown by Tillyard between $1 \mathrm{~A}$ and $\mathrm{Cu} 2$. The base 
of the wing is distorted by an irregularity in the surface of the rock.

(7) Pusillus. The costal space is broadened basally, not straight, as shown in the figure of the type; otherwise the shape of the wing is correctly represented. The pterostigma region is slightly darkened. The piece of limestone covering part of the posterior margin was removed, exposing the termination of $\mathrm{Cu} 1$; this vein is unbranched, not forked as supposed by Tillyard. There is a faint trace of a cross-vein between $\mathrm{Cu} 1$ and $\mathrm{Cu} 2$ at the base, but none is apparent distally.

From these observations on the type specimens and a comparison with the Harvard fossils, I believe it is clear that most of the characteristics which Tillyard used to distinguish the species do not hold. Furthermore, I am certain that none of the type specimens have the very base of the wing preserved. Most of the Harvard fossils also seem to have the base of the wing broken away at a point near the maximum width of the costal space; but several of the specimens show a more basal part, where the costal space narrows again, and the posterior margin bends inward considerably, the wing becoming subpetiolate. This I believe to represent the true shape of the wing in the

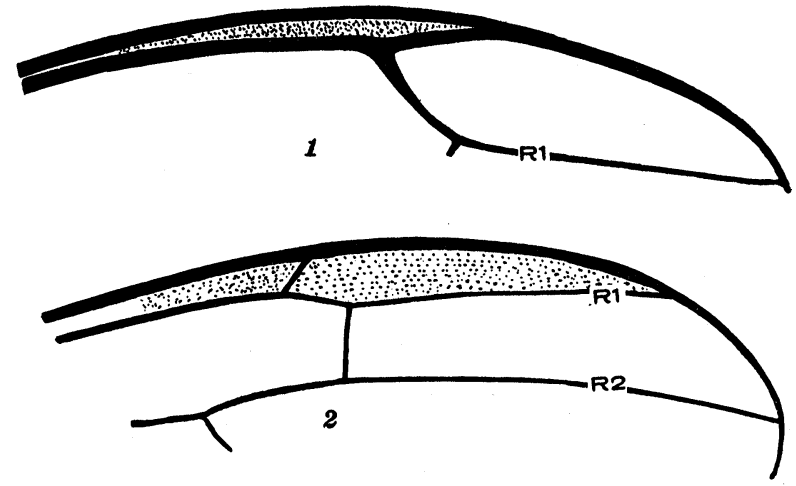

FIg. 1. Pterostigma of Protohymen elongatus n. sp.

FIg. 2. Pterostigma of Doter minor Sell., with cross-vein; specimen No. 3101, Mus. Comp. Zool. 
genus Doter (see fig. 13). In classifying the wings of these insects, therefore, I consider dunbari, gracilis kansasensis and stenobasis, to be one species, which must be called minor Sellards by priority. Affinis and stigmatazans seem to comprise another species, chiefly distinguished from minor by the remoteness of $1 \mathrm{~A}$ and $\mathrm{Cu} 2$; but these wings may be only the hind pair of the foregoing. By page precedence the name of the species must become affinis. Pusillus is removed all the other wings by its greater width.

\section{Doter minor Sellards}

Plate 2; text fig. 2; fig. 12, 13, 14

Doter minor Sellards, Amer. Journ. Sci., (4) 23: 355, 1907.

Doter minor Handlirsch, Denkschr. Akad. Wiss. Math. Naturw. (96) 82: 22, 1919.

Asthenohymen dunbari Tillyard, Amer. Journ. Sci. (5) 8 (44) : 117, 1924.

Asthenohymen gracilis Tillyard, Amer. Journ. Sci. .(5) 11 (62) : 66, 1926.

Asthenohymen kansasensis Tillyard, ibid, p. 67.

Asthenohymen stenobasis Tillyard, ibid, p. 68.

Length of body, excluding cerci, $4 \mathrm{~mm}$.; length of antennæ, $3.5 \mathrm{~mm}$; length of cerci, $10 \mathrm{~mm}$. Wing: length, 7-8 mm.; width, $2-3 \mathrm{~mm}$.; slender, subpetiolate, broadest beyond the middle; costal space narrow at base, widest opposite the point of divergence of $\mathrm{Cu} 1$ and $\mathrm{Cu} 2 ; \mathrm{R}^{+} \mathrm{M}$ straight at base, diverging upwards rather abruptly; $\mathrm{Cu} 1$ and $\mathrm{Cu} 2$ usually close together at base, diverging distally; $1 \mathrm{~A}$ fused with $\mathrm{Cu}$ at very base; pterostigma always present, but frequently only weakly preserved; cross-veins: one between R1 and R2+3; one between $\mathrm{R}^{+} 4$ and MA; two between MA and MP; two between MP and $\mathrm{Cu}$; two 
between $\mathrm{Cu} 1$ and $\mathrm{Cu} 2$; one between $\mathrm{Cu} 2$ and $1 \mathrm{~A}$; frequently a cross-vein is present in the pterostigmal region; posterior margin indented at the base.

Type: No. 62 Sellards collection, showing the thorax, abdomen, cerci, and folded wings.

In the Harvard collection there are twenty-five specimens of this species, aside from fragments; these are Nos. 30753094, and 3111-3115. The more important of these are as follows: No. 3078ab, complete wing; No. 3082ab, complete to very base; No. 3085ab, complete and finely preserved, the subcosta being very clear; No. 3086ab, complete, also with a distinct subcosta; No. 3111ab, nearly complete wings, with thorax and cerci ; 3112ab, base of wing, head, thorax, and fine antennae; No. 3113ab, a whole specimen, thorax well preserved; No. 3114ab, most of wing and cerci; No. 3115ab, parts of wings, head, thorax, abdomen, legs, antennæ and cerci, all finely preserved. Tillyard has figured (1926a, p. 61) the "remains of head, thorax and legs" as preserved in specimen No. 5043ab of the Yale collection, showing three ocelli and one mandible. I have examined this specimen under various types of illumination and from all angles, but have been unable to make out any of the details which Tillyard has figured.

\section{Doter affinis Tillyard}

Asthenohymen affinis Tillyard, Amer. Journ. Sci. (5), 11 (61) : 65, fig. 2.

Asthenohymen stigmatazans Tillyard, ibid, p. 66, fig. 4.

Length of wing, $7.5 \mathrm{~mm}$. ; width, $2.3 \mathrm{~mm}$. Venation similar to that of $D$. minor, but $1 \mathrm{~A}$ is remote from $\mathrm{Cu} 2$ and not connected with it by a cross-vein; wing broader at the base than minor; pterostigma weakly formed.

Holotype: No. 5050a Peabody Museum; counterpart in Tillyard collection. In the Harvard collection there is a complete wing of this species, No. 3095ab (F. M. Carpenter, collector). This species may represent the hind wing of minor. 


\section{Doter pusillus Tillyard}

Asthenohymen pusillus Tillyard, Amer. Journ. Sci., (5) 11 (61) : 68, fig. 7.

Length of wing, 5-7 mm.; width, 2-3 $\mathrm{mm}$. Wing broad, especially at the base, but the costal space is not quite so broad as in minor; pterostigma is rather well developed; $1 \mathrm{~A}$ is short and remote from $\mathrm{Cu} 2$, but is connected with it by a cross-vein.

Holotype: No. 5051, Peabody Museum. In the Harvard collection there are two fine specimens of this species: one of these (No. 3097ab) is about the size of the type, $5 \mathrm{~mm}$. long; the other is $7 \mathrm{~mm}$. long, but otherwise identical. As I have stated above, Tillyard erroneously thought that this species was characterized by a forked Cu1. Both the Harvard fossils show two cross-veins between $\mathrm{Cu} 1$ and $\mathrm{Cu} 2$, although only one was apparent in the faintly preserved holotype.
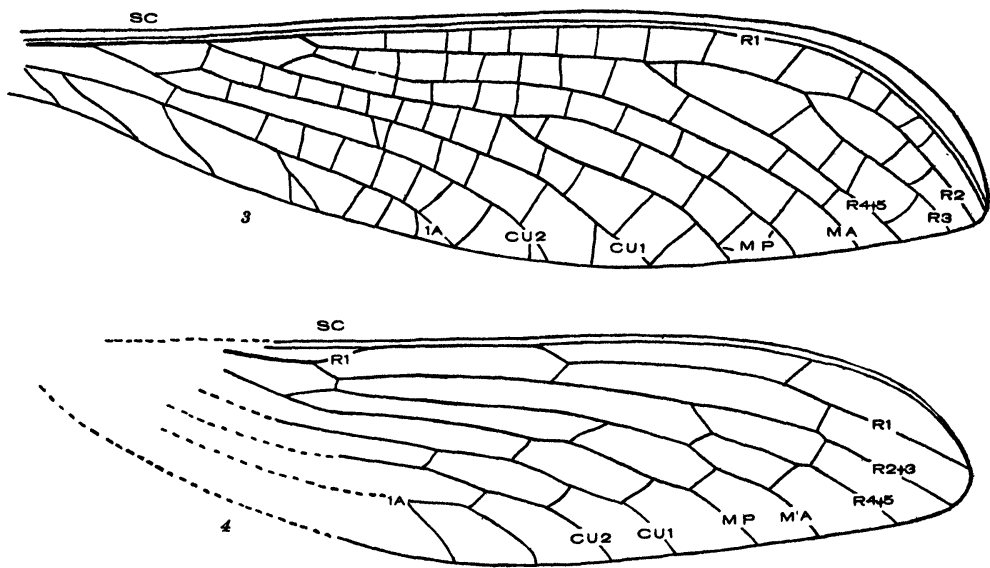

Fig. 3. Fore wing of Aspidohymen triangularis Brogn., from the Carboniferous of France (after Brongniart).

FIG. 4. Wing (hind?) of Aspidohymen extensus Mart., from Russian Permian (after Martynov). 


\section{The Venation of the Protohymenoptera}

Having considered the new fossils and the additional information which they give us on the wing structure of the Protohymenoptera, we are in a position to investigate the venation and to attempt to homologize the veins with those in other insects. Lameere, Martynov, and Tillyard have shown in recent years that the main longitudinal veins in an insect's wing are either convex or concave, and that the convexity or concavity is always constant for that vein. Thus, the subcosta, when viewed from the upper surface of the wing, is always concave $\left(^{-}\right)$, R1 always convex $\left(^{+}\right)$, Rs concave, etc. ${ }^{2}$ In the more primitive insects, or at least in those with a fairly complete venational system, the convexities and concavities are strongly developed. Consequently, a well preserved fossil wing of such a type has the relief of the veins also preserved, and this is a great aid in identifying the veins and homologizing them with those in the wings of recent insects. Of course in the case of fossils, the obverse half presents the impression of the ventral surface of the wing, so that when we look at this half, we see the veins in the same relief as if we were viewing the original wing from the dorsal surface; that is, Sc is concave, R1 convex, etc. Conversely, the reverse half of the fossil is formed by the impression of the upper surface of the wing, so that we see the veins in the same relief as if we were looking at the wing itself from below; that is, Sc is concave, R1 convex, etc. Now the "key" to the identity of the two halves of a fossil wing is the subcosta; for it is the first vein in the wing below the anterior margin and it is present in nearly all insects. The subcosta is therefore easily recognized by virtue of its position, and when we find it concave in one-half of the fossil, we know we are dealing with the obverse piece, with the convexities and concavities of the veins just as on the dorsal surface of the wing itself. When we find the subcosta convex, we know we have the reverse half, with the relief of the veins in the negative position.

${ }^{2}$ Of course when we state that a vein is convex or concave, we imply that we are observing the veins from the upper side of the wing. 
When I commenced my study of the Protohymenoptera in the Harvard collection, I was astonished to find that in the obverse halves of the fossils (with Sc concave) the convexities and concavities of the other veins were directly opposite those which Tillyard described as characteristic of the Protohymenoptera; all the veins which he had indicated as convex $\left(^{+}\right)$were concave $\left(^{-}\right)$in my specimens, and vice versa. The explanation of this became clear, however, when I examined the Yale types which Tillyard had studied. In Protohymen and Permohymen the subcosta is crowded between $R+M$ on one side and the costa on the other; only at the very base of the wing (see fig. 1) is it free and independent of these other veins, and here only can it be seen distinctly. In all the Yale specimens, as I have previously mentioned, the bases of the wings are either obliterated or very poorly preserved; consequently Tillyard was unable to see the subcosta where it was best developed. In the Doteridæ (Asthenohymenidæ) the subcosta is free from $R$ and the costa, but it is quite short. Tillyard seems to have had some difficulty in identifying the subcosta in the Yale specimens of Doter, and concluded that it was "obsolescent." He says, "A peculiarity about this genus is the difficulty of determining the exact limits of the obsolescent Sc, the main vein $R$, and the delicate traces of the basal portions of $\mathrm{M}$ and $\mathrm{Cu}$ running beneath. This seems to be due to the fact that both costa and $R$ are somewhat widened and flattened veins, while Sc and the basal part of $\mathrm{M}$ and $\mathrm{Cu}$ are very slender and faint. ... It is possible that both $\mathrm{Sc}$ and $\mathrm{Rs}$ are really fused with $\mathrm{R}$ right to its apex. ..." Here again I believe that Tillyard's difficulty was largely due to the fact that the bases of the wings of the Yale specimens of Doter were not well preserved, if preserved at all; this I have already mentioned in connection with the shape of the wings. The holotype kansanensis is the one exception to this, but when Tillyard examined this specimen, the base of the anterior margin was partly covered by a piece of limestone, as shown in his figure. When I studied the type, I removed this chip of rock with a needle, exposing the subcosta for nearly its full length. With the assistance of the photographer of the Peabody Museum I obtained a fine photograph 
of this specimen, and it is reproduced here to show how well the subcosta really is developed in Doter (fig. 12). Only one-half of this specimen is now at the Peabody Museum, the other being in Dr. Tillyard's collection; the Yale half has the subcosta strongly concave, and is therefore the obverse. Now, when I compared this half with the obverses in the Harvard collection, I found that the convexities and concavities of all the veins agreed exactly. This means that Tillyard, who was not able to locate the subcosta in his specmens, and who consequently lacked the key to the identification of the two halves of the fossils, confused the obverses with the reverses, so that all the veins which he thought were convex were really concave, and vice versa. Consequently the veins of the Protohymenoptera cannot be interpreted as Tillyard supposed, for his $\mathrm{R} 1$ is really a concave vein, his Rs convex, etc. Martynov also made the same mistake in his interpretation of the veins in the Russian Protohymenoptera, Aspidohymen extensus. Unfortunately, the whole anterior border of the specimen was obliterated and did not show the subcosta. Apparently Martynov assumed that Tillyard's idea of the convexities and concavities was correct and based his own interpretation of the veins in Aspidohymen on the reverse.

We have now to identify the veins in the protohymenopterous wings according to our corrected understanding of the convexities and concavities of the veins. But the interpretation of the veins in this group is by no means an easy task; even a casual examination shows that several of the veins which existed in the primitive insect wing have been lost. The venation of the Protohymenoptera has been reduced so far that I do not believe we can homologize the veins with those in other insects until we have learned something of the ancestral condition of the venation and determined which veins have disappeared.

Martynov has already concluded from the nature of the wing membrane and the position of the wings at rest that the Protohymenoptera were close relatives of the Megasecoptera. Fortunately many details of the body structure of the Commentry Megasecoptera have been made known to us through the researches of Brongniart 
(1893) and Lameere (1917), and we can now compare them with the corresponding features of the Protohymenoptera. All of the Megasecoptera possessed a pair of long multi-segmented cerci, identical with those which we have observed in the Protohymenoptera; no other insects which have been found (except a few Paleodictyoptera) had cerci of such a nature. The segmentation of the thorax and abdomen, the structure of the antennæ, and the contours of the head were also very similar to those of the Protohymenoptera. The fore legs of some of the Megasecoptera were undoubtedly raptorial (Lameere, 1917), while others were of the simple walking type, resembling those of the Doteridæ. The exact number of tarsal segments in the Megasecoptera is not known, but Lameere believed that he could distinguish five segments in one of the Commentry fossils. In Doter, as we have seen above, there were only three tarsal segments, but this difference is really of no significance, for in some of the recent orders the number of tarsal segments is equally variable. ${ }^{3}$

The body structure of the Protohymenoptera, therefore, not only agrees with Martynov's conclusions, but adds strong evidence in support of the view that the Protohymenoptera were very closely related to the Carboniferous Megasecoptera.

Let us now compare the wing venation of the two groups; can we derive that of the Protohymenoptera from the one found in the Megasecoptera? The most complete and detailed figures of the megasecopterous wings are those contained in Brongniart's classic account of the Commentry fossils, and I base my discussion of these wings chiefly on his work, for there are no unquestionable Megasecoptera known from the American Carboniferous. In particular, Brongniart's enlarged diagram of the wing of Aspidothorax is very useful and is reproduced here (text fig. 3). When we compare the wing of Protohymen with this figure, we at once note that there are two longitudinal veins less in the Protohymenopteron than in the Megasecopteron. In Aspidothorax the radial sector originates before the middle of the wing and gives rise to three

${ }^{3} \mathrm{As}$ in the Plectoptera, where the number is from five to one. 
branches, R2, R3 and $\mathrm{R} 4+5$. The next vein is the media, which is fused with $R$ basally according to Brongniart's figure; it diverges posteriorly a short distance before the origin of Rs, and then divides into its two main branches, MA $\left(^{+}\right)$and MP $\left({ }^{-}\right)$. Shortly after its origin MA bends upwards towards $R_{s}$ and is connected with it here by a short, stout cross-vein. MA is unbranched, but MP is forked near the middle of the wing. $\mathrm{Cu}$ separates from $\mathrm{R}$ close to the base of the wing and promptly divides into $\mathrm{Cu} 1$ and $\mathrm{Cu} 2$. In some of the Megasecoptera, as Mischoptera (plate 30, fig. 6), the anterior media (MA) not only bends towards Rs, but actually fuses with it for a short distance; and Cu1 diverges towards MP at its base. Now in Aspidohymen, the Russian Protohymenopteron (text fig. 4), Rs originates as in the Megasecoptera; R2+3 and $\mathrm{R}^{+}+5$ separate off as in Aspidothorax, but the former is unbranched. Hence, the structure of the radial sector in Aspidohymen is readily derived from that of the Megasecoptera by the elimination of the fork in $\mathrm{R} 2+3$.

When we pass to the more highly developed wing of Protohymen, we find that MA has fused with Rs at its base, just as in some of the Megasecoptera. The free basal piece of MA, between its origin and junction with Rs, is very long and decidedly convex, not flat like a true crossvein, as it was interpreted by Tillyard and Martynov.

Now if we examine the posterior media in the Protohymenoptera we at once note that it is not forked as in the Megasecoptera; the posterior branch of MP is the other vein which has been lost in the Protohymenoptera. In certain of the Megasecoptera, as I have already mentioned, the basal part of $\mathrm{Cu} 1$ curves upwards towards $\mathrm{M}$, just as MP approaches Rs. Unfortunately, this part of the wing of Aspidohymen is missing, but in Protohymen permianus there is a short vein, resembling a cross-vein, between the base of $\mathrm{Cu} 1$ and $\mathrm{R}$ (see fig. 11). In Protohymen elongatus, Permohymen, and Doter, Cu1 bends upward and actually fuses with $R$ at this point. Now in order to obtain this condition present in Protohymen from that of the Megasecoptera, we have only to suppose that $\mathrm{Cu} 1$ coalesced with MP at the base just as MA fused with $R$. According to this interpretation the "cross-vein" between 
$\mathrm{Cu} 1$ and $\mathrm{R}$ at the base is really the free, short piece of the stem of M. This tendency for MA to coalesce with the radial sector, and MP to coalesce with $\mathrm{Cu} 1$ is found in nearly every order of insects where there is a marked reduction in the venation. Whether my conception of the changes in the structure of the media is correct or not, the fact remains that the convex vein just below Rs in the Protohymenoptera can only be MA, and the concave vein before $\mathrm{Cu} 1$ must be MP. The nature of the modifications which resulted in the elimination of the two veins is perhaps not so obvious; but by merely carryng out the coalescence already suggested or begun in the Megasecoptera, we obtain conditions so strikingly similar to what we actually find in the Protohymenoptera that I believe the process outlined above is the correct one.

So few are the specializations in the wings of the Protohymenoptera over those of the Megasecoptera that we have in this fact further proof of the very close affinity of these two orders. It is true that we postulated such a relationship at the beginning of our discussion of the wing venation in the Protohymenoptera; but the ease with which we can derive one type from the other is itself an indication of such an association. From all aspects, therefore-wing structure, body structure, and wing venation-the evidence points to the one conclusion. I am therefore led to agree with Handlirsch's original suggestion, that these insects are not only allied to the Megasecoptera, but are actually members of that order. They undoubtedly constitute a distinct suborder (Protohymenoptera), as specialized Permian representatives of the true Carboniferous Megasecoptera (suborder Eumegasecoptera).

There are two modifications in the wings of some of the Protohymenoptera which were not considered above, because they are obviously of no more than generic or specific importance. I refer to the broad wings of Permohymen, and the formation of a pterostigma in the Protohymenidæ. Some students of insect phylogeny may object to the idea of deriving insects with broad wings like those of Permohymen from insects with narrow or subpetiolate wings like those of the Carboniferous Megasecoptera; for petiolation is usually considered a modification of the normally 
broad wings, exemplified in the Paleodictyoptera. But when the venation of the wing is not altered during the process of change in the shape of the wing, the broadening is of specific or even individual importance only. Many examples of this can be found in recent groups. In the Asilid genus Leptogaster the wings are frequently subpetiolate, while in Ospriocerus and Pogonosoma they are remarkably broad. In the Empidæ the wings are often subpetiolate, but in some species, as Rhamphomyia, they are enormously broadened, and almost oval. In this latter family also the broadening of the wings is frequently a secondary sexual characteristic of the male. But in none of these insects is the venation changed as the wings widen, aside from shift in the direction of the veins in the anal region. On the other hand, when the process of change in shape is accompanied by numerous modifications of the venation, then the breadth is of great phylogenetic value. I have already shown the impossibility of deriving the anisopterous dragon-flies from the petiolate Zygoptera, for here numerous changes in the venation would be necessary. In the genus Permohymen, however, we are dealing with the former type of modification in the shape of the wing, where there is no alteration of the veins. Aside from slight difference in the direction of the anal veins, the venation is exactly like that of Protohymen, which is as petiolate as the Carboniferous Megasecoptera. The assignment of such a broad-winged insect as Permohymen to the Megasecoptera is therefore not at all objectionable.

The pterostigma in the Protohymenidæ is a simple structure, much less of a specialization than Tillyard had supposed. In Aspidohymen there is no pterostigma, R1 being remote from the costal margin at this point; but there is a strong, oblique cross-vein connecting R1 with the costa in the pterostigma region. In. Protohymen permianus R1 fuses with the costa up to the pterostigmal area, where it diverges downward to the apex of the wing; the pterostigmal cross-vein is present, and even more strongly developed ( $\mathrm{R} 1$ of Tillyard). In Protohymen elongate $\mathrm{R} 1$ is slightly removed from the costa in the pterostigmal region, 
and the wing membrane between the veins is thickened and darkened. In Permohymen $\mathrm{R} 1$ is even more removed from the costa; the pterostigmal cross-vein is only weakly formed, as a slight thickening of the apical edge of the pterostigma itself. The Doteridæ have only a very feeble pterostigma; $\mathrm{R} 1$ is remote from the margin, and the area between is slightly darkened. In most specimens there is no pterostigmal cross-vein, but in other specimens of the same species there is a definite cross-vein here. The pterostigma in the Protohymenoptera is very primitive in structure and does not, therefore, eliminate them from the Megasecoptera; it is merely another slight specialization developed in connection with the reduction of the venation.

\section{RELATIONSHIP WITH THE HYMENOPTERA}

Now in demonstrating that the Protohymenoptera are megasecopterous we do not necessarily prove that they have no connection with the Hymenoptera. Only the wording of the question becomes slightly changed: were the Hymenoptera evolved from the Megasecoptera? If we attempt to derive the Hymenoptera in this way, we at once remove the order from all the other holometabolous insects, unless we postulate that they also originated from the Megasecoptera. The latter assumption hardly deserves consideration, for the Megasecoptera were far more specialized than the lower members of the panorpoid orders. The former proposition-that the Hymenoptera were evolved separately from the other holometabolous insects and developed complete metamorphosis independently - has already been offered by Tillyard (1926b). He says, "The fossil evidence is now fairly strong that there were three distinct groups of holometabolous insects which evolved a pupal stage independently of one another in the Permian period. These are (a) the Mecopteroid orders, namely, Mecoptera, Neuroptera, Paramecoptera, Paratrichoptera, Diptera, Trichoptera, Lepidoptera, and Siphanaptera; (b) the Hymenopteroid orders, Protohymenoptera and Hymenoptera; and (c) the Coleopteroid orders, Protocoleoptera, Coleoptera, and their parasitic offshoot, Strep- 
siptera." 4 Although I cannot agree with Tillyard's statement that the fossil evidence indicates this polyphyletic origin of holometabolism, it is clear that the question of the relationship between the Protohymenoptera and Hymenoptera is a complicated one and not easily answered.

So far as the body structure of the Protohymenoptera is concerned, there is really nothing definite either way. Of course we should hardly have expected to find such well developed cerci in the direct ancestors of the Hymenoptera, but that is only an indication that the body structure of the Protohymenoptera was much more primitive than the wing venation. The three-segmented tarsi of Doter are more specialized than the five-segmented ones in the primitive Hymenoptera; but some of the more primitive, unknown Protohymenoptera may have had five-segmented tarsi also. I believe, however, that Martynov's arguments, based on the nature of the wing membrane and the position of the wings at rest, are definite proof that the Protohymenoptera had no connection with the Hymenoptera; at least his arguments are sufficient to make Tillyard's conclusions seem doubtful.

But even if it is true that the Hymenoptera are derivatives of the Protohymenoptera, and that the venation of the former has evolved from that of the latter, the venational system which Tillyard proposed for the Hymenoptera must be changed, for I have shown above that Tillyard had erroneously interpreted the veins in the Protohymenoptera by confusing the obverses with the reverses. The veins which he designated as M1 and M2 in the Hymenoptera (1924, p. 119, fig. 4) would be branches of $\mathrm{Rs}$; his $\mathrm{M} 3+4$ would be MA; his Cu1 would be MP; and so forth with the rest of the veins. In other words, if we

${ }^{4}$ A few remarks may be necessary on the Carboniferous sycopteron symmetricum Bolton (Commentry). The specimen on which this species was based is poorly preserved, and lacks the base and apex of the wing. Bolton considered the fossil to be a possible relative of the psocids, but Tillyard (1927) regarded it as a Carboniferous representative of the Protohymenoptera. Martynov thinks that Bolton's opinion is "not improbable." For my own part, I fail to find anything in the fossil which is at all reminiscent of the Protohymenoptera; the few features of the wing that are preserved seem to be more orthopteroid than anything else. 
accept Tillyard's theory that the Protohymenoptera were the ancestors of the Hymenoptera, we must reject his interpretation of the hymenopterous venation based upon that association and substitute another one founded upon the corrected interpretation of the protohymenopterous wings advanced in this paper. Conversely, if his system of hymenopterous venation is the correct one, we must reject his doctrine of the origin of the Hymenoptera.

As I have mentioned above there are a few structures in the Hymenoptera (such as the polynephric Malphigian system) which isolate the group slightly from the other holometabolous insects; but so many other features are identical in the Hymenoptera and panorpoid orders that we can safely say that the comparative morphology of all these insects, especially in the developmental stages, demonstrates satisfactorily that the Hymenoptera arose in common with the other holometabolous forms (see Crampton, 1927, etc.). It is true that the venation of the Hymenoptera, as interpreted by Comstock, MacGillivary, and Tillyard, is not in complete agreement with that of the Mecoptera and allies; but Dr. Martynov, after an extensive study of the wings of the Hymenoptera, has concluded (1930) that the "venation in the Hymenoptera, though very specialized, shows many features of similarity with that of the Megaloptera and Mecoptera, thus proving that the Hymenoptera evolved from ancestors somewhat intermediate between the Megaloptera, Raphidioptera, and Mecoptera. The resemblance of the wings of the Megasecoptera, or the Protohymenoptera to those of the Hymenoptera (and Mecoptera) is purely superficial." Although Martynov's paper is still in the process of publication, it seems already certain that the Protohymenoptera and the rest of the Megasecoptera have nothing in common with the Hymenoptera.

\footnotetext{
"Martynov has suggested that since the name "Protohymenoptera" is not appropriate for these fossils, it should be changed; and he proposes "Synsecoptera." This procedure does not seem practicable to me, for we already have other "Proto" orders (as Protodonata) which are no longer regarded as ancestral to the recent order concerned. This policy also means that investigators with diverse views on the affinities of the fossil would refer to the order under different names.
} 


\section{BIBLIOGRAPHY}

Brongniart, C. 1893. Researches pour servir a l'histoire des Insectes Fossiles de temps primaires. St. Etienna, 1893.

Carpenter, F. M. 1930a. The Lower Permian Insects of Kansas. Part I. Introduction and the Order Mecoptera. Bull. Mus. Comp. Zoölogy, 70 (2) : 69-101. 1930b. The Lower Permian Insects of Kansas. Part II. The Orders Paleodictyoptera, Protodonata, and Odonata. Amer. Journ. Sci., (5) 20 (119).

Cockerell, T. D. A. 1927. Hymenoptera and a Caddis Larva from the Miocene of Colorado. Ann. Mag. Nat. Hist., (9) 20 : 429-435 (esp. 434).

Crampton, G. C. 1919. A Phylogenetic Study of the Mesothoracic Terga and Wing Bases in Hymenoptera, Neuroptera, Mecoptera, Diptera, Trichoptera, and Lepidoptera. Psyche, 21 (3) : 58-64.

1927. Eugereon and the Ancestry of the Hemiptera, Psocids and Hymenoptera. Bull. Brook. Ent. Soc., 22 (1) : 1-17.

Handlirsch, A. 1919. Revision.der palæozoischen Insekten. Denkschr. Akad. Wiss. Wien Math. Naturw. Kl., 96: $1-81$.

1927. Handbuch der Zoologie, 4 (ed. W. Kükenthal).

Lameere, A. 1917. Revision Sommaire des Insectes Fossiles du Stephanien de Commentry. Bul. Mus. Nat. Hist. Paris, 23: 141-201.

1927. L'année Zool. Rec. Inst. Zool. Torley-Rousseaux, 1: 205-231.

Martynov, A. V. 1930. New Permian Insects from Tikhie Gory, Kazan Province. I. Palæoptera. Trav. Mus. Geol. Acad. Sci. U. R. S. S., 6: 69-86.

Sellards, E. H. 1907. Types of Permian Insects, Part II. Amer. Journ. Sci. 23: 345-355.

Tillyard, R. J. 1924. Kansas Permian Insects. Part III. The New Order Protohymenoptera. Amer. Journ. Sci.

(5) 8 (44): 111-112. 
1926a. Kansas Permian Insects. Part VI. Additions to the Orders Protohymenoptera and Odonata. ibid. (5) 11 (61) : 58-73.

1926b. Fossil Insects in Relation to Living Forms. Nature, 117: 828-830.

1926c. Insects of Australia and New Zealand. Sydney. 1927. The Ancestry of the Order Hymenoptera. Trans. Ent. Soc. Lond. 1927 (2) : 307-318.

\section{ExPLANATion of Plates}

\section{Plate 15}

Fig. 1. Wings of Protohymen permianus Till.

Fig. 2. Fore wing of Protohymen elongatus, n. sp.

Fig. 3. Wings of Permohymen schucherti Till.

\section{Plate 16}

Fig. 4. Wing of Doter minor Sell.

Fig. 5. Front leg of D. minor; specimen No. 3115a, Mus. Comp. Zoölogy.

Fig. 6. Middle leg of $D$. minor; specimen No. 3115a.

Fig. 7. Antenna of $D$. minor; specimen No. 3115a, 3112a.

Fig. 8. Head, prothorax, and mesothorax of D. minor (lateral) : No. 3115a.

Fig. 9. Thorax of D. minor (dorsal) : No. 3113a.

Fig. 10. Last five abdominal segments and cerci of $D$. minor; No. 3115a.

\section{Plate 17}

Fig. 11. Photograph of obverse of Protohymen permianus Till., specimen No. 3060a, Mus. Comp. Zoölogy.

Fig. 12. Photograph of holotype of Asthenohymen kansasensis Till.; No. 5044a, Peabody Museum.

Fig. 13. Photograph of wing of D. minor, specimen No. 3087a, Mus. Comp. Zoölogy.

Fig. 14. Photograph of part of cerci of D. minor, specimen No. 3115a, Mus. Comp. Zoölogy. 

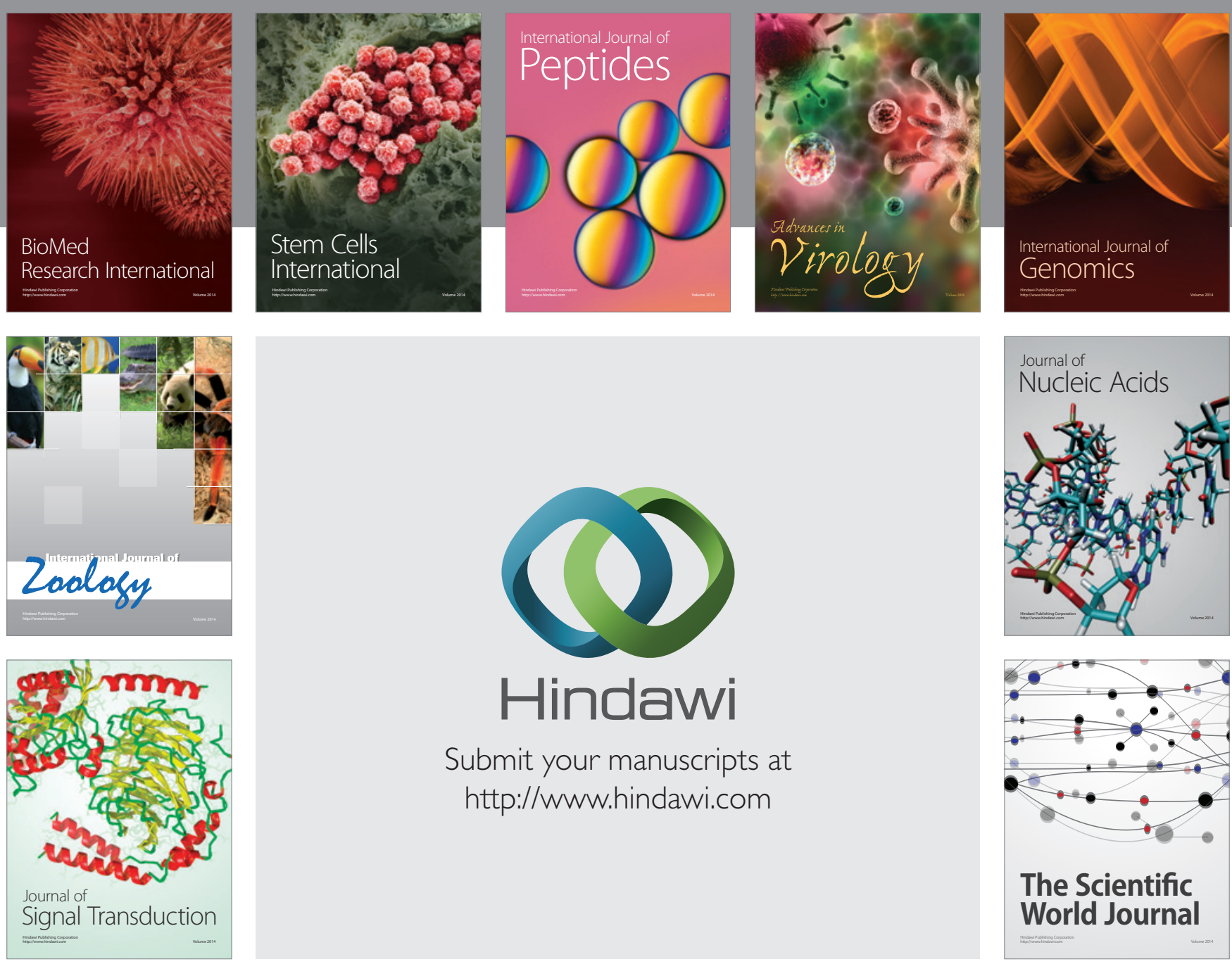

Submit your manuscripts at

http://www.hindawi.com
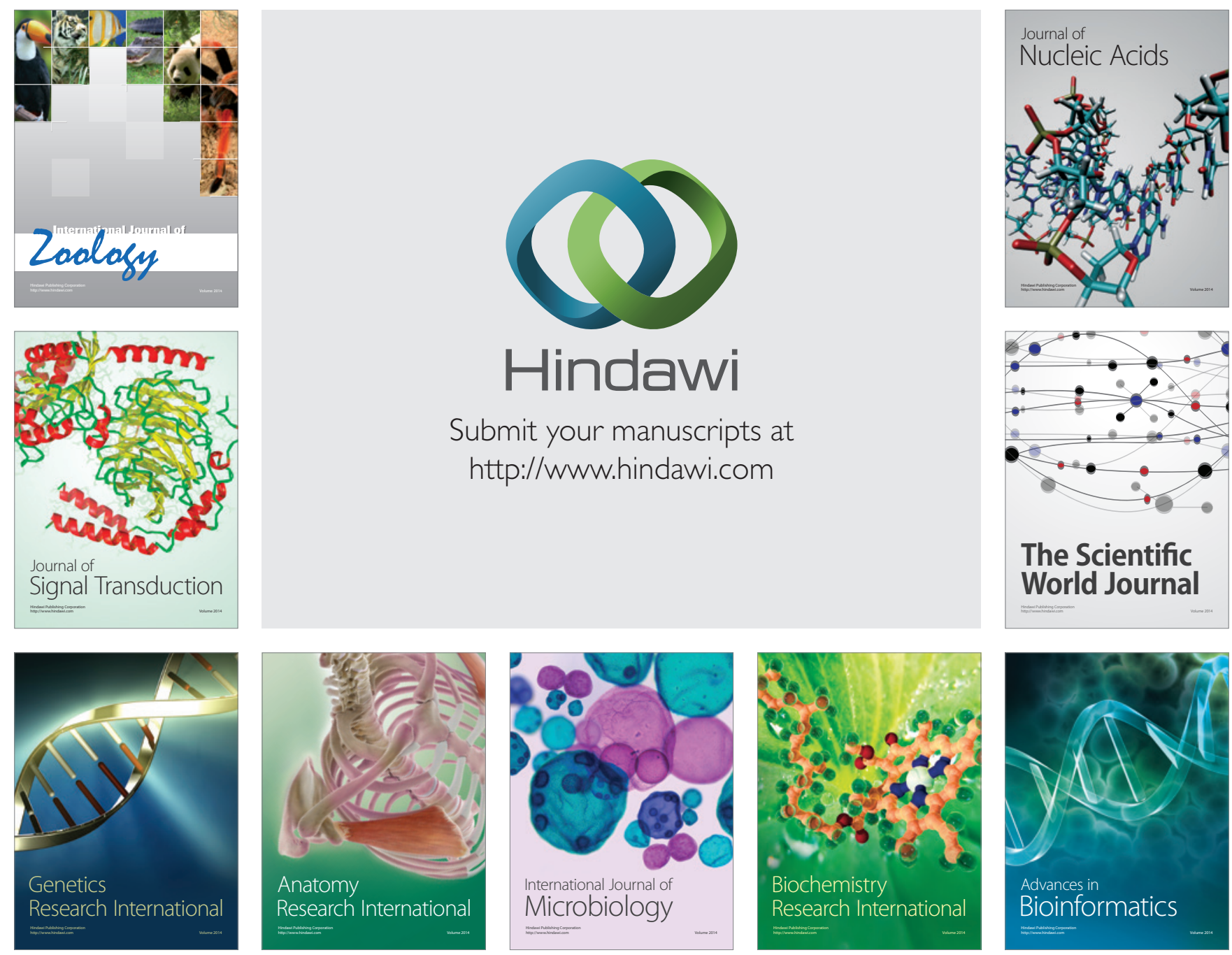

The Scientific World Journal
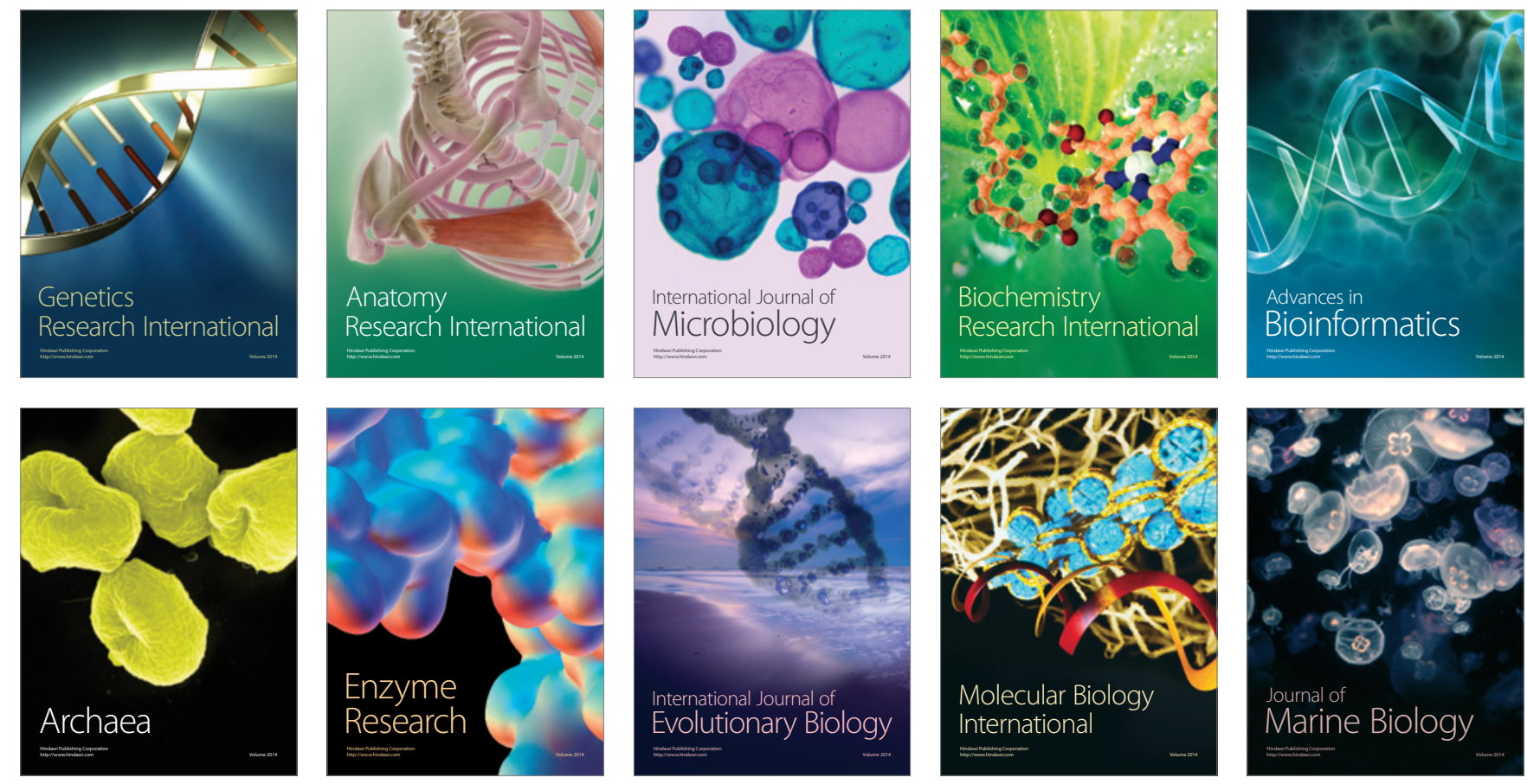